\title{
The Impact of Human Resource Practices on Employee Commitment and Employee Retention in Telecom Sector of Pakistan: Exploring the Mediating Role of Employee Loyalty
}

\author{
Benish Hussain Janjua, Amir Gulzar \\ Foundation University Islamabad \\ Foundation University Islamabad
}

\begin{abstract}
The study is carried out to explore the impact of human resource practices on employee retention and employee Commitment in the telecom Sector of Pakistan. It further investigates the mediating role of employee loyalty with HRM practices, Employee Commitment and Employee Retention. The data was collected through questionnaire. About 250 Questionnaires were filled from the employees of different telecom firms in Rawalpindi and Islamabad. For interpretation and analysis of data Correlation, Regression and Sobel Tests were conducted. The results showed that different human resource practices have a significant impact on the employee commitment and employee retention. Further the result revealed that loyalty mediates the relation of HRM and Employee Commitment and the relationship of HRM and Employee Retention.
\end{abstract}

\section{Introduction:}

Human resource is deemed to give competitive advantage to companies because in addition to production related capacities it also takes human capital into account. It is easy for competitors to copy other resources like technology and capital but the human resource are distinctive and not easy to imitate. According to Khatri (1999) cited in Tiwari (2012) personnel of a company are one of the most important factors that provide flexibility and adaptability to organizations. With mediocre employees a business can do well but with capable employees a business flourishes at a greater pace. In the same way the employees with terrible qualities can make a business collapse shifting to a downfall. Having a pool of good employees and developing their loyalty becomes extremely important and a continuing challenge. Constant and systematic approach to recruitment and selection and training and development reduces moving from one job to another job and ensures long-term employment; internal promotion practices with a little recognition given to seniority and the implementation of the productivity-linked wage system would create a more committed employee towards the company.

It is crucial that the management tries to retain company's best workforce and maintain their commitment to the organization in order to attract additional quality employees. It is important for researchers to have a basic focus of researchers in their knowledge creation for employment, organizations and related fields (Scarpello, Ledvinka, \& Bergman, 1995).

Sohailet (2011) enlightened that employee retention as an important process. Nowadays, organizations are experiencing a balance of power shifting from employers to employees. Employees can be retained and satisfied within those organizations which keep on learning that how to keep their employee satisfaction at the highest level. If there is excess of turnover then it indicates towards a basic problem within the company and for such organization it is important to be familiar with how to retain employees. Attracting in retaining the employees in emerging countries is highly desired practice of the high performance organizations. One of the most used ways of retaining employees is compensating them more than they are earning. Also after some years, the competition will be fierce and having the best talent in the company will be a challenge.

Rathnaweerage, R.(2010), Human Resource Management practices and their outcomes such as employee satisfaction, commitment and retention. The study is carried out in Sri-Lanka. The respondents were the Srilankan Public sector bankers. The result of the study showed that Most of the HRM practices have a positive impact on the Employee retention, Employee Commitment and Employee Satisfaction.

In Pakistan the concept of HRM practices with Employee Commitment and Employee Retention is never carried out specifically in the telecom sector of Pakistan. The study is not only focusing on the relationship between independent and dependent variable but has an additional mediating variable (Loyalty) to investigate the relationship which is as an additional contribution to the study.

So the study aims to observe the impact of Human resource management practices on employee retention and employee commitment in the five telecommunication companies of Pakistan. Human resource management practices taken are recruitment and selection, training and development, performance appraisal, compensation and social benefits and grievance handling system. Furthermore, loyalty of an employee is taken 
as the mediating variable here. Therefore, it is hoped that the study can contribute to the growing literature by examining the impact of human resource management practices on employee's retention and commitment in Pakistan context.

\section{Objective of the Study}

1. To explore the relationship of HRM practices and Employee Commitment

2. To explore the relationship of HRM practices and Employee Retention.

3. To examine the relationship of HRM practices and Loyalty

4. To examine the relationship of Loyalty and Employee Commitment

5. To prospect the relationship of Loyalty and Employee retention

6. To inspect the mediating role of Loyalty on the relationship of HRM practices and Employee Commitment

7. To explore the mediating role of Loyalty on the relationship of HRM practices and Employee Retention.

\section{Significance of the Study}

Currently this research would be significant in diagnosing the success of HRM practices. The Study has its importance in explaining the implementation of HRM practices and their Contribution towards the success keeping the employee within the organization. The study excellence lies in the facts on how to increase the Employee Commitment and to gain the employee loyalty by lowering the turnover rate. The result of the Study would help in developing a better understanding on how to manage the HRM practices keeping in view the dimensions of Employee Commitment, Employee Retention and Loyalty. This research is the guidance tool for the telecom companies as it provides the company with the information that fair HRM practices has greater impact on the Employee retention rate and their commitment to the firm.

\section{Review Of Literature}

According to Amstrong (2009) Human resource management (HRM) is a strategy of incorporating approach to employment, development of those employees and working for well being of people in an organization. The five broader categories of Human resource management are people staffing, learning and development, compensation management, performance appraisal and employee relations. Oya Erdil \& Ayue Gunsel states that for the proper achievement of firm strategy, the creation of capable personnel should start from the very initial level i.e. selection of employees according to the skills and behaviors that are desired in accordance with the context of the company.

Khan et. al (2012) concluded that training is deemed by employees to impact on their productivity and also has a positive effect over organization's performance. Training produces effects on two things: Job skills enhancement (Skill enhancement is giving the employees' awareness with new practices encouraging the skills of the workers related to a specific job) and Promotion of employees (In a competitive environment, a company invests not only in technological advancements but also the creation of human capital through extensive training). However, research study by Shah et. Al (2012) suggested that training has a considerable effect on employee development which creates a worthy effect on the performance of an organization. Development of employees through learning and intellectual capabilities expansion makes the working on job maintained at a higher level which successively increases the organizational performance (Kira et. al (2010) cited in Shah et. al (2012). According to Riaz \& Ramay (2010) job satisfaction is the employee's positive attitude towards a job and performance appraisal leads to career development which ultimately leads to job satisfaction. Similarly Yasminet (2012) concluded that HR systems impact the organization's performance and one of the key factors for the growth of telecom sector. While, Mohammad et. Al (2009) found out that incentives have a positive impact of organizational performance but did not affect the relationship between HR practices and efficiency of the organization (an investigation within manufacturing companies of Malaysia). So, a good HR system can enhance the performance of the organization even if incentives are not incorporated.

Correspondingly, Hooi Lai Wan stated that as Japan is a labor intensive country so it needs to essentially analyze the role of HR policies to enhance employee loyalty. Syed \& Yan (2012) tried to see the association between high performance human resource management practices and job rotation in the telecom sector of Pakistan which revealed that there is a positive association between the two variables. The factors that enhance the relationship are employee empowerment, job rotation (knowledge, skills and abilities boost), Merit based promotions and performance based pay are surely related with employee job satisfaction. Gardner et al. (2003) demonstrated the relationships between HR practices and organizational commitment in addition to operational and financial performance measures. Employees who are managed in accordance with the HR practices turn out to be highly committed to their organization. So, overall operating expenses lessen and profitability increases. 
Based on the above discussion following hypothetical interaction and hypothesis may be inferred:

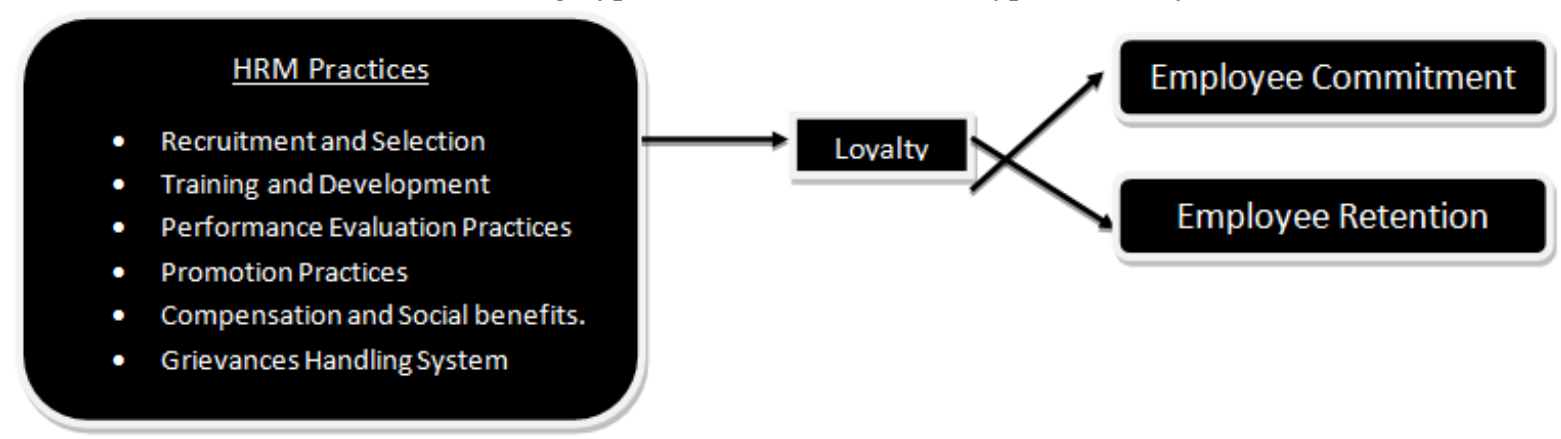

Source: Researchers' Proposed Model

\section{Hypothesis:}

H-1 Loyalty positively influences the Employee Commitment.

H-2 Loyalty positively influences the Employee Retention.

H-3 Fair recruitment and Selection positively influence strong Employee commitment.

H-4 Fair Recruitment and selection leads to high Employee Retention.

H-5 Training and development positively influences strong Employee commitment.

H-6 Training and development leads to high Employee Retention.

H-7 Fair Performance Evaluation positively influences strong Employee commitment.

H-8 Fair Performance Evaluation leads to high Employee Retention.

H-9 Promotion Practices positively influence strong Employee commitment.

H-10 Promotion Practices lead to High Employee Retention.

H-11 Fair Compensation and Social Benefits positively influence Employee Commitment

H-12 Fair Compensation and Social Benefits positively influence the Employee Retention

H-13 Grievance Handling System influences positively on Employee Commitment

H-14 Grievance Handling System influences positively on Employee Retention

H-15 Loyalty mediates the relationship of Recruitment and Selection and Employee Commitment.

H-16 Loyalty mediates the relationship of Training and Development and Employee Commitment.

H-17 Loyalty mediates the relationship of Performance Evaluation and Employee Commitment.

H-18 Loyalty mediates the relationship of Promotion Practices and Employee Commitment.

H-19 Loyalty mediates the relationship between Fair Compensation and Social Benefits and Employee Commitment

H-20 Loyalty mediates the relationship between Grievance Handling System and

Employee Commitment

H-21 Loyalty mediates the relationship of Recruitment and Selection and Employee Retention.

H-22 Loyalty mediates the relationship of Training and Development and Employee retention.

H-23 Loyalty mediates the relationship of Performance Evaluation and Employee retention.

H-24 Loyalty mediates the relationship of Promotion Practices and Employee Retention.

H-25 Loyalty mediates the relationship between Fair compensation Management and Social Benefits and Employee Retention.

H-26 Loyalty mediates the relationship between Grievance Handling System and Employee Retention

\section{Methodology}

The Research Study is causal and Cross-Sectional in nature inspecting the impact of HRM practices on Employee Retention and Employee Commitment with a mediating role of Loyalty in Telecom sector of Pakistan. Questionnaire of Rathnaweerage, R. (2010) is selected for data collection..The first part of the Questionnaire was to measure the demographics and the second part was to assess the information related to HRM practices, Employee Commitment, Employee Retention and Loyalty. Data was collected from 250 employees of telecom companies that were Telenor, Warid, U-fone, Zong and Mobilink. The response rate is $95 \%$.

Cronbach's Alpha reliability for each variable was above 0.7 ensuring that the data is internally consistent. 


\section{Data Analysis and Discussion}

Regression, Correlation and Sobel Test were conducted to analyze the data and to inspect the hypotheses. The Sobel Test is conducted but before that correlation and regression was applied as it is one of the perquisites of Sobel Test.

\subsection{Hypothesis Testing}

Table 4.1.1 Regression Analysis of Employee Commitment and Employee Retention on Loyalty

\begin{tabular}{|l|c|c|c|c|l|l|}
\hline & \multicolumn{2}{|c|}{ Employee Commitment* } & \multicolumn{3}{c|}{ Employee Retention* } \\
\hline & Beta & $\mathrm{t}$ & Sig. & Beta & t & Sig. \\
\hline Loyalty & 0.952 & 10.662 & 0.000 & 0.983 & 8.626 & 0.000 \\
\hline
\end{tabular}

*dependent variable

Table 4.1.2 Regression Analysis of HRM practices on Employee Commitment and Employee Retention respectively.

\begin{tabular}{|l|l|l|l|l|l|l|}
\hline \multicolumn{4}{|c|}{ Employee Commitment* } & \multicolumn{3}{c|}{ Employee Retention* } \\
\hline Independent Variables & \multicolumn{1}{|c|}{ Beta } & \multicolumn{1}{|c|}{$\mathrm{t}$} & \multicolumn{1}{|c|}{ Sig. } & Beta & $\mathrm{t}$ & Sig. \\
\hline Recruitment and Selection & 0.923 & 26.131 & 0.000 & 0.847 & 17.283 & 0.000 \\
Training and Development & 0.007 & 0.81 & 0.935 & 0.029 & 0.311 & 0.756 \\
Performance Evaluation & 0.127 & 1.388 & 0.168 & 0.041 & 0.446 & 0.656 \\
Promotion Practices & 0.87 & 0.951 & 0.343 & 0.099 & 1.082 & 0.282 \\
$\begin{array}{l}\text { Compensation and Social } \\
\text { Benefits }\end{array}$ & 0.780 & 13.518 & 0.000 & 0.734 & 11.738 & 0.000 \\
Grievance Handling System & 0.965 & 39.819 & 0.000 & 0.878 & 19.939 & 0.000 \\
\hline
\end{tabular}

*dependent variable

The first hypothesis of the study was that Loyalty positively influences the employee commitment. According to the table of regression Analysis p-values shows the significant relationship of the loyalty and employee commitment hence hypothesis stood true. The impact of the loyalty as per Beta value i.e. 0952 with employee commitment has found almost $95 \%$. The second hypothesis stated that loyalty positively influences the employee retention. According to the table of regression Analysis p-values shows the significant relationship of the loyalty and employee retention proving the hypothesis true. The impact of the loyalty as per Beta value i.e. .0983 on Employee Retention is found almost $98 \%$.

The third hypothesis is that the fair recruitment and selection positively influence employee commitment. According to the table of regression analysis there is a significant relationship. The impact of recruitment and selection as per Beta value i.e. 0.923 on employee commitment which is $92 \%$. The fourth hypothesis of the study was that fair recruitment and selection significantly influence employee retention. According to the table, there is a significant relationship. The impact of recruitment and selection as per Beta value i.e. 0.847 on employee retention which is $85 \%$. The fifth hypothesis is that training and development positively influence employee commitment is rejected by the results shown in the regression table as per pvalue. The sixth hypothesis is training and development positively influences employee retention is also rejected due to insignificant $\mathrm{p}$-value. The seventh hypothesis that fair performance evaluation system positively influence employee commitment proved wrong as due the insignificant p-value. According to the table of regression analysis there is no significant relationship. The eighth Hypothesis was that fair performance appraisal system positively influences employee retention. According to the table of regression analysis there is no significant relationship so null hypothesis is accepted. The ninth hypothesis was that promotion practices positively influences employee commitment. According to the table of regression analysis there is no significant relationship.

The tenth hypothesis that Promotion Practices positively influence Employee Retention could not proved as the p-value was not significant. The eleventh hypothesis was that fair compensation and social benefits positively influence employee commitment. According to the table of regression analysis there is a significant relationship. The impact of fair compensation and social benefits as per Beta value i.e. 0.780 on employee commitment which is $78 \%$. The twelfth hypothesis was that fair compensation and social benefits positively influences employee retention. According to the table of regression analysis there is a significant relationship. The impact of fair compensation and social benefits as per Beta value i.e. 0.734 on employee retention which is $73.4 \%$. The thirteenth hypothesis was that grievance handling system positively influences employee commitment. According to the table of regression analysis there is a significant relationship. The 
impact of grievance handling system as per Beta value i.e. 0.965 on employee commitment which is $96.5 \%$. The fourteenth hypothesis was that grievance handling system positively influences employee retention. According to the table of regression analysis there is a significant relationship. The impact of grievance handling system as per Beta value i.e. 0.878 on Employee Retention which is $87.8 \%$.

\begin{tabular}{|l|l|l|}
\hline & Sobel test Statistics & p-Value \\
\hline $\begin{array}{l}\text { L as a mediator in the relationship of } \\
\text { Recruitment and selection and Employee Commitment }\end{array}$ & 18.15861025 & 0 \\
\hline $\begin{array}{l}\text { L as a mediator in the relationship of } \\
\text { Compensation and Social Benefits and Employee Commitment }\end{array}$ & 11.935055 & 0 \\
\hline $\begin{array}{l}\text { L as a mediator in the relationship of } \\
\text { Grievances Handling System and Employee Commitment }\end{array}$ & 21.44488899 & 0 \\
\hline $\begin{array}{l}\text { L as a mediator in the relationship of } \\
\text { Recruitment and Selection and Employee Retention }\end{array}$ & 20.35637979 & 0 \\
\hline $\begin{array}{l}\text { L as a mediator in the relationship of } \\
\text { Compensation and Social Benefits and Employee Retention }\end{array}$ & 12.450627 & 0 \\
\hline $\begin{array}{l}\text { L as a mediator in the relationship of } \\
\text { Grievances Handling System and Employee Retention }\end{array}$ & 24.96027439 & 0 \\
\hline
\end{tabular}

Table 4.1.3 Sobel Test for the mediation of Loyalty

\section{L: Loyalty}

Sobel test was conducted for the testing of mediation among the variables. As training and development, performance evaluation and promotion practices could not found significant in the regression analysis so their test for mediation was not checked as they failed to fulfill the criteria for mediation. So the hypotheses 16, 17, 18, 22, 23 and 24 could not proved true. The fifth hypothesis of the study was that the loyalty mediates the relationship of recruitment and selection and employee commitment. The p-value of the Sobel test shows that mediation exist and hypothesis proved true. The nineteenth hypothesis stated that loyalty mediates the relationship between fair compensation and social benefits and employee Commitment. The Pvalue of the Sobel Test shows that mediation exist hence the hypothesis proved true. The twentieth hypothesis of the study was that Loyalty mediates the relationship between grievance handling System and employee commitment. The p-value of the Sobel test shows that Mediation exists and hypothesis proved true. The twentyfifth Hypothesis of the study was that loyalty mediates the relationship between fair compensation and social benefits and employee retention. The P-value of the Sobel Test shows that mediation exist hence the hypothesis proved true. The twenty-sixth hypothesis of the study was that loyalty mediates the relationship between grievance handling system and employee retention. The p-value of the Sobel test shows that Mediation exist and hypothesis proved true.

\subsection{Conclusion:}

The study concluded the following:

1. Loyalty has greater influence on employee retention as compare to employee commitment.

2. The recruitment and selection has greater impact on employee commitment as compare to employee retention.

3. The impact of compensation and social benefits on employee Commitment is greater as compare to the impact on employee retention.

4. Employee commitment and employee retention has a positive relationship with the grievances handling system where grievance handling system has more influence on employee committeemen.

5. Loyalty acts as mediator in the relationship of recruitment and selection and Employee Commitment, relationship of compensation and benefits and Employee Commitment and relationship of grievances handling system and Employee Commitment.

6. Loyalty acts as mediator in the relationship of recruitment and selection and employee retention, relationship of compensation and benefits and employee retention and relationship of grievances handling system and employee retention.

\section{References:}

[1]. Armstrong, M. (2009) Armstrong's Handbook of Human Resource management Practice. Replika Press Private Limites

[2]. Chen, Z. (2001) Further investigation of the outcomes of loyalty to supervisor: Job satisfaction and intention to stay.

[3]. Oya Erdil \& Ayue Gunsel Gebze., Relationships Between Human Resource Management Practices, Business Strate- Gy Fit And Firm Performance.

[4]. Khan, N., Ahmed, S. F., Ibrahim, M., Shahid, M. K. (2012). Impact of On- job training on performance of Telecom Industry".

[5]. Riaz, A. \&Ramay, M. (2010).Antecedents of job satisfaction: A study of telecom sector

[6]. Shah, S. S. H., Fatima, M., Waris, S., Aziz, J., Jaffari, A. R. (2012). The Causal Relationship of Training on Organization PerformanceKira,

[7]. M., F.M. Van Eijnatten and B.B. David, (2010).Crafting sustainable work: Development of personal resources. 
[8]. Yasmin, R., Waris, S., Jaffari, A. R., Aziz, J., Wasiq Ejaz1 andFatima, M. (2012). The Impact of HR Dimensions on organizational performance

[9]. Mohammad et. al (2009) Human Resource Practices and Organizational Performance Incentives as Moderator.

[10]. Wan, H. L. Employee Loyalty at the workplace: the impact of Japanese Style of Human Resource Management

[11]. Syed ,N.\& Yan, L. X. (2012). Impact of High Performance Human Resource Management Practices on Employee Job Satisfaction: Empirical Analysis

[12]. Gardner, T. M., Moynihan, L. M., Wright, P. M. (2003). The impact of HR practices on the performance of business units

[13]. Shoaib, M., Noor, A., Tirmizi S. R., Bashir, S. (2009). Determinants of Employee Retention in Telecom Sector of Pakistan.

[14]. Rathnaweerage, R. (2010), Human Resource Management practices and their outcomes such as employee satisfaction, commitment and retention.

[15]. Michel, Zaitouni M., Sawalha, N. N., AdilElSharif. (2011). The Impact of Human Resource Management Practices on Organizational Commitment in the Banking Sector in Kuwait

[16]. Sohail, N., Muneer A., Tariq. Y.T. (2011). Losing Your Best Talent: Employee Retention The Dilemma Of Textile Industry

[17]. Khatri, N.,(1999). Emerging issues in Strategic HRM IN Singapore

[18]. Michel, Zaitouni M., Sawalha, N. N., AdilElSharif. (2011). The Impact of Human Resource Management Practices on Organizational Commitment in the Banking Sector in Kuwait

[19]. Tiwari, P. (2012). Human Resource Management Practices: A comprehensive review 